\title{
SEROPREVALENCE OF HCV INFECTION AMONG PATIENTS IN A TERTIARY CARE HOSPITAL IN BANGALORE
}

\author{
Rashmi K. S1, Faiza Samreen², Anjana Gopi³, Swati Jain 4
}

${ }^{1}$ Associate Professor, Department of Microbiology, KIMSH \& RC, Bangalore.

2Junior Resident, Department of Microbiology, KIMSH \& RC, Bangalore.

3 Professor and HOD, Department of Microbiology, KIMSH \& RC, Bangalore.

4 Junior Resident, Department of Microbiology, KIMSH \& RC, Bangalore.

\begin{abstract}
BACKGROUND

Hepatitis $\mathrm{C}$ virus (HCV) is a parenterally transmitted hepatitis virus infecting approximately $3 \%$ of the world population. Chronic infection with HCV is one of the major causes of liver cirrhosis and hepatocellular carcinoma. A high prevalence of HCV infection in haemodialysis patients has been reported.

Aims and Objectives- To determine the prevalence of HCV by antibody testing among patients, with special reference to patients undergoing haemodialysis.
\end{abstract}

\section{MATERIALS AND METHODS}

Total number of 700 patients attending the OPD (out of whom 37 were on dialysis) were screened for HCV seropositivity using the HCV TRI-DOT card test and Cobas Anti-HCV II assay.

Statistical Analysis Used- Percentages and Chi-square test.

Settings and Design- It is a prospective study conducted at a tertiary care hospital in Bangalore. The study was conducted between December 2014 and May 2015.

\section{RESULTS}

Out of 700 individuals tested during the study period, 59 (8.4\%) were tested positive for HCV antibodies. HCV seropositivity was found in $31 / 37$ (83.8\%) haemodialysis patients and 28/663 (4.2\%) non-haemodialysis patients with a significant $p$ value of $<0.05$. Out of total positives, there were 14 female patients (23.7\%) and 45 male patients (76.3\%). There was a high rate of seropositivity in patients between 51-60 years of age (27.1\%). Mean duration of haemodialysis was three to four years and two to three dialyses were done every week. Liver enzymes Aspartate transaminase (AST), Alanine transaminase (ALT) levels were found to be elevated among three HCV positive haemodialysis patients and ten HCV positive non-haemodialysis patients.

\section{CONCLUSION}

This study showed a high seroprevalence among dialysis patients, with greater prevalence among males and in patients above 50 years of age.

\section{KEYWORDS}

Chronic Hepatitis, Hepatitis C Virus, Haemodialysis, Seroprevalence.

HOW TO CITE THIS ARTICLE: Rashmi KS, Samreen F, Gopi A, et al. Seroprevalence of HCV infection among patients in a tertiary care hospital in Bangalore. J. Evolution Med. Dent. Sci. 2017;6(31):2541-2544, DOI: 10.14260/Jemds/2017/550

\section{BACKGROUND \\ HCV is a RNA virus belonging to Flaviviridae family, genus Hepacivirus. HCV affects patients who undergo multiple blood transfusions, intravenous drug users and those undergoing maintenance haemodialysis patients. HCV infection can lead to chronic hepatitis, liver cirrhosis and hepatocellular carcinoma.[1],[2],[3] The success of current treatment of HCV is $11-30 \%$. The dearth of an efficient vaccine emphasises the need for periodic surveillance of the disease to determine specific measures for disease prevention and control.[4]}

\section{Financial or Other, Competing Interest: None}

Submission 12-03-2017, Peer Review 07-04-2017,

Acceptance 12-04-2017, Published 17-04-2017.

Corresponding Author:

Dr. Rashmi K. S,

D1, Footprints Good Earth Malhar,

Doddabele Road, Kambipura,

Kengeri Post, Behind RRMC,

Bangalore-560074.

E-mail: rashminaga05@gmail.com

DOI: $10.14260 /$ jemds $/ 2017 / 550$

\section{(c) (i) $\$$}

Hence, a study was undertaken to estimate the seroprevalence of HCV in general population, with special reference to haemodialysis patients. Understanding the current seroprevalence of HCV in a tertiary care setup gives us an opportunity to assess a large population and provides insight into the discordant knowledge surrounding the prevention and precautions to prevent transmission of $\mathrm{HCV}$, which in turn warrants stringent vigilance and education regarding precautions, prevention and treatment of $\mathrm{HCV}$.

\section{MATERIALS AND METHODS}

It is a prospective study conducted at a tertiary care centre in Bangalore. The study was conducted between December 2014 and May 2015. Total number of 700 patients attending the General OPD and Urology OPD (out of whom 37 were on dialysis) were screened for HCV seropositivity. Blood samples were drawn from the patients and serum was separated within two hours after blood sampling. Each patient's sera were divided into two $0.5 \mathrm{~mL}$ aliquots. One sample was stored at $-20^{\circ} \mathrm{C}$ and the test was performed with the second sample. The sera were tested for antibodies against HCV 
proteins using the HCV TRI-DOT card test (J. Mitra \& Co. Pvt. Ltd, India) and Cobas Anti-HCV II assay (Roche Diagnostics, USA).

Statistical analysis was done using percentages and Chisquare test.

\section{RESULTS}

Out of 700 individuals tested during the study period, 59 (8.4\%) were tested positive for HCV antibodies. HCV seropositivity was found in $31 / 37(83.8 \%)$ haemodialysis and 28/663 (4.2\%) non-haemodialysis patients with $\mathrm{P}$ value of zero. [Table-1]. Out of total positives, there were 14 female $(23.7 \%)$ and 45 male patients (76.3\%). [Figure-1]. The seropositivity was found to be high in patients between 51 60 years of age (27.1\%). [Figure-2]. Mean duration of haemodialysis was three to four years and two to three dialyses were done every week. Liver enzymes Aspartate transaminase (AST), Alanine transaminase (ALT) were evaluated among the positives, AST and ALT levels were found to be elevated among three HCV positive haemodialysis patients and ten HCV positive non-haemodialysis patients [Figure 3]. The comorbid conditions in haemodialysis patients include Type 1 and type 2 Diabetes Mellitus (45\%), HTN- Hypertension (23\%), CRF- Chronic renal failure (20\%), Hepatitis B virus infection (7\%) and HIV infection (5\%). [Figure 4].

\begin{tabular}{|c|c|c|}
\hline & Positive & Negative \\
\hline Haemodialysis & 31 & 06 \\
\hline Non-haemodialysis & 28 & 635 \\
\hline
\end{tabular}

Table I. HCV Seropositivity among Haemodialysis and Non-haemodialysis Patients

\begin{tabular}{|c|c|c|}
\hline Year & Seroprevalence & Studies \\
\hline $\begin{array}{r}1995- \\
2000\end{array}$ & $0.87-1.85 \%$ & $\begin{array}{c}\text { Theodore et al, }[5] \\
\text { Chowdhary et al[6] }\end{array}$ \\
\hline $\begin{array}{r}2001- \\
2005\end{array}$ & $2-7.9 \%$ & $\begin{array}{c}\text { Khaja et al, }[7] \text { Arora et al, }[8] \\
\text { Bhattacharya et al[9] }\end{array}$ \\
\hline $\begin{array}{r}2006- \\
2010\end{array}$ & $0.1-1 \%$ & $\begin{array}{c}\text { Arora D et al, }[10] \\
\text { Bommanahalli et al[11] }\end{array}$ \\
\hline $\begin{array}{c}2011- \\
2015\end{array}$ & $1.17-1.8 \%$ & $\begin{array}{c}\text { Vallab et al, }[12] \\
\text { A. Chakraborthy et al[13] }\end{array}$ \\
\hline \multicolumn{3}{|c|}{ Table II. Seropositivity among General } \\
Population from 1995-2015
\end{tabular}

\begin{tabular}{|c|c|c|}
\hline Year & Seroprevalence & Studies \\
\hline $1995-2000$ & $4.3-28 \%$ & Mukhopadhya $^{[1]}$ \\
\hline $2001-2005$ & $1.5-5.9 \%$ & $\begin{array}{c}\text { Reddy et al[14] } \\
\text { G A Reddy et al }{ }^{[15]}\end{array}$ \\
\hline $2006-2010$ & $1.5 \%-27.7 \%$ & $\begin{array}{c}\text { Lavanchy et al[16] } \\
\text { Jasuja et al }{ }^{[17]}\end{array}$ \\
\hline $2011-2015$ & $1.1-33.4 \%$ & $\begin{array}{c}\text { Kranthi et al[18] } \\
\text { Mittal G et al[19] } \\
\text { Malhotra } \mathrm{R}^{[20]}\end{array}$ \\
\hline \multicolumn{2}{|c|}{ Table III. Seropositivity among Patients Undergoing } \\
Maintenance Haemodialysis from 1995-2015
\end{tabular}

Table II and Table III: Trends in HCV infection over a decade.
Seropositivity among males and females

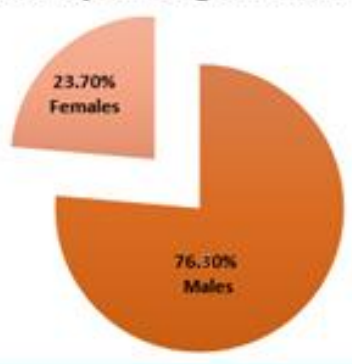

Figure 1. Gender Distribution of HCV Seropositivity

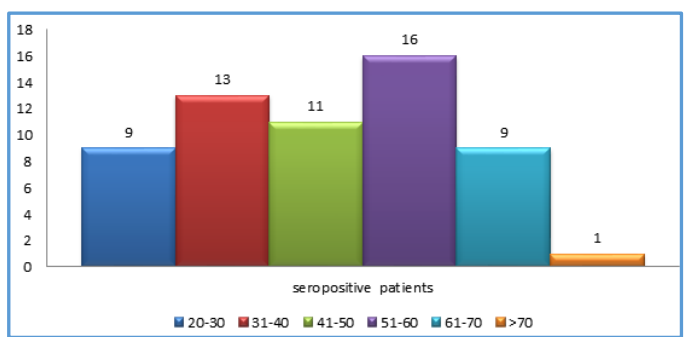

Figure 2. Age Distribution among Seropositive Patients

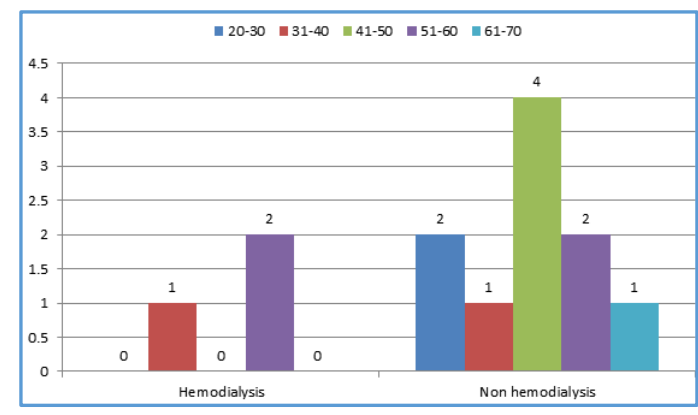

Figure 3. Status of raised Liver Enzymes (AST and ALT) among HCV Positive Patients

AST- Aspartate transaminase, ALT- Alanine transaminase

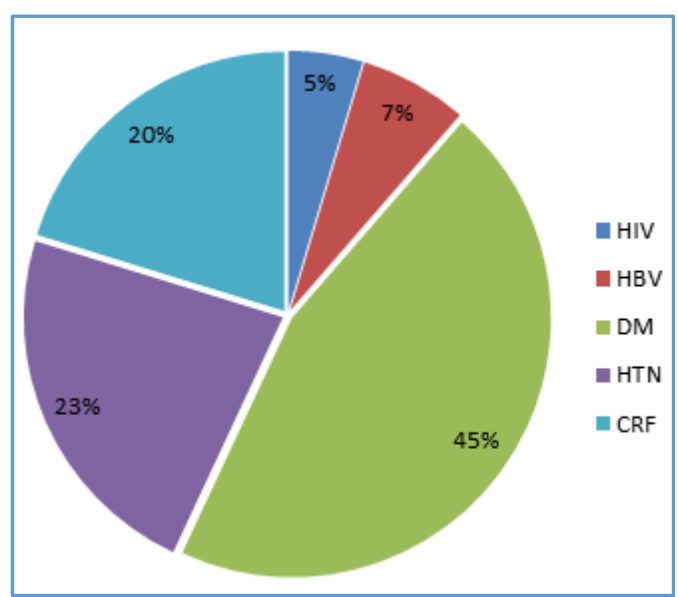

Figure 4. Comorbid Conditions in Haemodialysis Patients

HIV- AIDS, HBV- Hepatitis B virus, Type 1 and type 2 Diabetes Mellitus, HTN- Hypertension, CRF- Chronic renal failure.

\section{DISCUSSION}

Hepatitis continues to be a serious problem in chronic dialysis units even after the introduction of serological tests and vaccines for HBV infection and universal precaution standards. The available data suggests that HCV is a major 
cause of NANB hepatitis throughout the world.[21] The spread of HCV in haemodialysis units is declining, but the prevalence of HCV continues to remain high in this group of patients. [4]

The overall HCV seroprevalence in our study was observed to be $8.4 \%$. The seropositivity was found to be high in patients of age group 51-60 years $(27.1 \%)$ with male preponderance $(76.3 \%)$, which was similar to the studies done by Asima Banu et al and Kranthi Kosaraju et al[2],[11] [Figure 1 and 2].

In some studies by Preeti et al and Mohammed Ali et al, gender had no correlation with anti-HCV antibodies.[4],[22] The high prevalence of alcoholism (leading to chronic liver disease) among males may seem to contribute to higher seroprevalence of HCV. A higher number of males are blood donors compared to females, hence males are screened more often. ${ }^{[4]}$

The seroprevalence of HCV in our study was found to be 83.8\% in haemodialysis patients. Several studies from India and other countries have reported prevalence rates ranging from $1 \%$ to $68 \% .[23],[24],[25],[26]$ Health care procedures related to nosocomial infections, unsafe drug injection practices, and blood transfusions are key factors in HCV transmission. In haemodialysis facilities, the most common lapses of healthcare quality are contamination of dialysis systems, inadequate disinfection and cleaning of environmental surfaces, improper contact of health care staff with equipment and patients and mishandling of parenteral medications. Although the precise modes of transmission have not been identified, breakdown in standard infection control practices, physical proximity to an infected patient and sharing of dialysis machines are possible causes for increased prevalence of $\mathrm{HCV}$ in haemodialysis patients. Therefore, strict adherence to universal precautions and careful attention to hygiene are recommended to reduce the transmission of HCV in dialysis units. [21], [11]

Contradictory to our finding, other studies show prevalence of 1- 28\%.[1],[21],[11],[26],[17] This low prevalence can be attributed to the fact that the risk of acquiring HCV infection in haemodialysis units has decreased partially after the isolation of $\mathrm{HCV}$ positive patients in separated haemodialysis units. Chances of false positives or false negatives cannot be completely ruled out. Hence, we need to detect HCV RNA by PCR for confirmation.

Non-haemodialysis patients showed a seroprevalence of $4.2 \%$ which is in conformity with various other studies showing prevalence between $4-45 \% .{ }^{[4]}$

The mean duration of haemodialysis was two years compared to other studies which showed higher mean duration of six years by Mohammed Ali et al and 7.2 years by Jeffers et al.[22], [21] HCV was found to be more prevalent among patients who had undergone haemodialysis for a longer duration owing to greater exposure over the years.

As seen in Figure- 3, our study showed raised AST and ALT levels among three HCV positive haemodialysis patients and ten HCV positive non-haemodialysis patients which is in consensus with other studies such as Fabrizio[24] and Marinaki et al.[27] Haemodialysis patients with chronic hepatitis due to HCV infection have serum aminotransferase levels which are at the upper limit but still within the normal range, although higher compared to HCV negative haemodialysis patients. There is no definite explanation regarding the lower transaminase levels observed in haemodialysis patients, although several aetiologies have been postulated-

1. AST levels reflect the high metabolic activity of homocysteine due to its high values observed in haemodialysis patients and their correlation with low AST.

2. Haemodilution.

3. Vitamin B6 deficiency and Uremic toxins.

4. Dialysis procedure and activation of IFN- $\gamma$ and lymphocytes. ${ }^{[14]}$

Changing trends in HCV prevalence over past 20 years (as depicted in Table II and III) has shown decrease in percentage probably due to improved technology, safer techniques of blood transfusion and increased awareness regarding the disinfection of dialysis machines by improving the surveillance system of HCV, better education of nurses in the dialysis centres. However, despite reduction of hepatitis $\mathrm{C}$ prevalence, haemodialysis patients still comprise a high risk group.

Although the third generation ELISA is considered highly sensitive, a major drawback of this assay is that a substantial number of haemodialysis patients will still test negative for anti-HCV antibodies even with detectable hepatitis C viraemia.[7]In addition to this, it is now well documented that the commercially available third-generation ELISA cannot be used to detect the viral infection in Indian patients owing to genotype variations.[7] To overcome this problem, sensitive diagnostic peptide-based enzyme immunoassays that are cost-effective and designed to detect HCV infection in Indian patients have been developed. Presently, an indigenous peptide-based HCV EIA kit is available (Xcyton ${ }^{\mathrm{TM}}$, Bangalore, India). Significance of detection of HCV-RNA in patient sera by RT-PCR lies in the observation that a positive result in RTPCR is indicative of active viral replication. [7] Therefore, it would be pertinent to detect HCV-RNA by RT-PCR as it is the most sensitive and specific assay for HCV detection. However, due to hitherto undetermined prevalence, non-availability and financial constraints refrain us from performing the RTPCR test.

\section{CONCLUSION}

This study showed a high seroprevalence among dialysis patients with greater prevalence among males and more frequently in the age group of 50 years and above. The risk is greater among haemodialysis patients as they frequently undergo blood transfusion. Simple measures such as enforced general asepsis rules, careful disinfection and equipment sterilisation, routine testing of patients, serial determination of hepatic enzymes should be the common practice in the dialysis centres.[8]

Nonetheless, now, the Centres for Disease Control and Prevention (CDC) does not recommend dedicated machines, patient isolation, or a ban on re-use in haemodialysis patients with HCV infection.

The guidelines for preventing HCV infection in haemodialysis settings recommend fundamental infection control practices and routine screening of haemodialysis patients for HCV. Isolating HCV-infected patients or using dedicated machines for such patients are not advocated, except as necessary during local outbreaks. [28]

Infection with $\mathrm{HCV}$ is unique and represents an enigma to the clinician for the simple reason that majority of the patients remain asymptomatic, with fluctuating liver enzyme 
levels. Thus, rather than developing novel therapeutic strategies, development of a vaccine that can prevent the viral infection should be of paramount importance. A major impediment in this direction is the variation in the genome of HCV observed either as quasi-species or as genotypes.

A known HCV infected patient is the most important reservoir of infection. Therefore, prompt screening, strict adherence to universal precautions and educational programs to increase awareness about safe blood transfusion can contribute to reduce the burden of this disease.

\section{REFERENCES}

[1] Mukhopadhya A. Hepatitis C in India. J Biosci 2008;33(4):465-73.

[2] Banu A, Latha B, Aravind A, et al. A study on low seroprevalence of $\mathrm{HCV}$ in hemodialysis patients in South India. Am J Adv Nur Res 2015;2(Suppl 2):58-61.

[3] Mendez-Sanchez N, Motola-Kuba D, Zamora-Veldes D, et al. Risk factors and prevalence of Hepatitis virus B and $\mathrm{C}$ serum markers among nurses at a tertiary care hospital in Mexico city, Mexico: a descriptive study. Annals of Hepatol 2006;5(4):276-80.

[4] Mindolli PB, Salmani MP. Seroprevalence of Hepatitis $C$ virus in a tertiary care centre in Vijaypur, Karnataka, India. Int J Curr Microbiol App Sci 2015;(4 Suppl 10):956-5.

[5] Theodore Sy, Jamal MM. Epidemiology of Hepatitis C Virus (HCV) Infection. Int J Med Sci 2006;3(2):41-6. www.medsci.org

[6] Chowdhury A, Santra A, Chaudhuri S, et al. Hepatitis C virus infection in the general population: a community-based study in West Bengal, India. Hepatology 2003;37(4):802-9.

[7] Khaja MN, Munpally SK, Hussain MM, et al. Hepatitis C virus: The Indian scenario. Current Science 2002;83(3):219-23.

[8] Arora DR, Sehgal R, Gupta N, et al. Prevalence of parenterally transmitted hepatitis viruses in clinically diagnosed cases of hepatitis. Indian J Med Microbiol 2005;23(1):44-7.

[9] Bhattacharya S, Badrinath S, Hamide A, et al Seroprevalence of hepatitis $C$ virus in a hospital based general population in South India. Indian J Med Microbiol 2003;21(1):43-5.

[10] Arora D, Arora B, Khetarpal A. Seroprevalence of HIV, HBV, HCV and syphilis in blood donors in Southern Haryana. Indian J Pathol Microbiol 2010;53(2):308-9.

[11] Basavaraj B, Rudramma J, Mallikarjuna S, et al. Seroprevalence of hepatitis $\mathrm{B}$ and hepatitis $\mathrm{C}$ viral infections among blood donors of Central Karnataka, India. Int J Med Sci Pub Health 2014;3(3):285-8.

[12] Bharadwaj BVG, Vazhavandal G, Sasirekha N, et al. Seroprevalence of Hepatitis C virus among health care workers of a rural teaching hospital in Tamil Nadu. Journal of Evolution of Medical and Dental Sciences 2014;3(1):32-7.

[13] Chakraborty A, Pramanik SB, Roy DS, et al. A Retrospective study on the sero-prevalence of hepatitis c infection in a tertiary care hospital in Kolkata, India. Int J Curr Microbiol App Sci 2015;4(3):115-23.
[14] Etik DO, Ocal S, Boyacioglu AS. Hepatitis C infection in hemodialysis patients: a review. World J Hepatol 2015;7(6):885-95. http://doi.org/10.4254/wjh.v7.i6.885

[15] Reddy GA, Dakshinamurthy KV, Neelaprasad P, et al Prevalence of HBV and HCV dual infection in patients on haemodialysis. Indian J Med Microbiol 2005;23(1):41-3.

[16] Lavanchy D. Evolving epidemiology of hepatitis C virus. Clinical Microbiology and Infection 2011;17(2):107-15.

[17] Jasuja S, Gupta AK, Choudhry R, et al. Prevalence and associations of hepatitis $\mathrm{C}$ viremia in hemodialysis patients at a tertiary care hospital. Indian J Nephrol 2009;19(2):62-7.

[18] Kosaraju K, Faujdar SS, Singh A, et al. Hepatitis viruses in hemodialysis patients: an added insult to injury? Hepatitis Research and Treatment 2013;2013:4. Article ID 860514.

[19] Mittal G, Gupta P, Thakuria B, et al. Profile of hepatitis $B$ virus, hepatitis $C$ virus, hepatitis $d$ virus and human immunodeficiency virus infections in hemodialysis patients of a tertiary care hospital in Uttarakhand. J Clin Exp Hepatol 2013;3(1):24-8.

[20] Malhotra R, Soin D, Grover P, et al. Hepatitis B virus and hepatitis $\mathrm{C}$ virus co-infection in hemodialysis patients: a retrospective study from a tertiary care hospital of North India. J Nat Sci Biol Med 2016;7(1):72-4.

[21] Jeffers LJ, Perez GO, de Medina MD, et al. Hepatitis C infection in two urban hemodialysis units. Kidney Int 1990;38(2):320-2.

[22] Assarehzadegan MA, Shakerinejad G, Noroozkohnejad $\mathrm{R}$, et al. Prevalence of Hepatitis C and B infection and HCV genotypes among Hemodialysis patients in Khuzestan Province, Southwest Iran. Saudi J Kid Dis Transpl 2009;20(4):681-4.

[23] Manal M, El Kholy, Mohamed A. Hepatitis C virus in adolescent hemodialysis patients. Medical Res J 2013;12(2):76-80.

[24] Fabrizi F. Hepatitis C virus infection and dialysis: 2012 update. Hindawi Pub Coporation., ISRN Nephrology 2013;2013:11. Article ID 159760. http://dx.doi.org/10.5402/2013/159760.

[25] Somi MH, Keivani H, Ardalan MR, et al. Hepatitis C virus Genotypes in patients with end stage renal disease in East Azerbaijan Iran. Saudi J Kid Dis Transpl 2008;19(3):461-5.

[26] AK Reddy, Murthy KV, Lakshmi V. Prevalence of HCV infection among hemodialysis patients: survey by antibody and core antigen detection. Indian J Med Microbiol 2005;23(2):106-10.

[27] Marinaki S, Boletis JN, Sakellariou S, et al. Hepatitis C in hemodialysis patients. World J Hepatol 2015;7(3): 548-58. http://doi.org/10.4254/wjh.v7.i3.548.

[28] Bianco A, Bova F, Nobile CGA, et al. Healthcare workers and prevention of hepatitis $\mathrm{C}$ virus transmission: exploring knowledge, attitudes and evidence-based practices in hemodialysis units in Italy. BMC Infectious Diseases 2013;13:76-87. 